THE ECONOMICS OF BELONGING 



\section{The Economics of Belonging}

\section{A Radical Plan}

to Win Back the

Left Behind and

Achieve Prosperity

for All

Martin Sandbu

PRINCETON UNIVERSITY PRESS

PRINCETON AND OXFORD 
Copyright $\odot 2020$ by Martin Sandbu

Requests for permission to reproduce material from this work should be sent to permissions@press.princeton.edu

Published by Princeton University Press

41 William Street, Princeton, New Jersey 08540

6 Oxford Street, Woodstock, Oxfordshire OX20 1TR

press.princeton.edu

All Rights Reserved

ISBN 978-0-691-20452-9

ISBN (e-book) 978-0-691-20453-6

British Library Cataloging-in-Publication Data is available

Editorial: Sarah Caro and Josh Drake

Production Editorial: Mark Bellis

Jacket Design: Karl Spurzem

Production: Erin Suydam

Publicity: James Schneider and Kate Farquhar-Thomson

Copyeditor: Ashley Moore

The writing of this book was made possible by the generous award of a Journalist Fellowship from the Friends Provident Foundation

This book has been composed in Adobe Text and Gotham

Printed on acid-free paper. $\infty$

Printed in the United States of America

$\begin{array}{llllllllll}10 & 9 & 8 & 7 & 6 & 5 & 4 & 3 & 2 & 1\end{array}$ 
For Theo 
